\title{
Topical Fluorouracil
}

National Cancer Institute

\section{Source}

National Cancer Institute. Topical Fluorouracil. NCI Thesaurus. Code C125194.

: A topical formulation containing the antimetabolite 5-fluorouracil (5-FU), with antineoplastic activity. Upon topical administration, 5-FU is converted into the active metabolite 5-fluoroxyuridine monophosphate (F-UMP), which competes with uracil during RNA synthesis and inhibits RNA processing. Conversion of 5-FU into another active metabolite, 5-5-fluoro-2'-deoxyuridine-5'-O-monophosphate (F-dUMP), inhibits thymidylate synthase; this results in the depletion of thymidine triphosphate (TTP), one of the four nucleotide triphosphates used in DNA synthesis, and thus inhibits DNA synthesis. Altogether, this prevents the proliferation of tumor cells locally. 